\title{
Nickel Carcinogenesis Mechanism: DNA Damage
}

\author{
Hongrui Guo ${ }^{1,2, \dagger}$, Huan Liu ${ }^{1,+}$, Hongbin $W_{u}{ }^{1, \dagger}$, Hengmin Cui $1,2,3, * \mathbb{D}$, Jing Fang ${ }^{1,2}$, \\ Zhicai Zuo ${ }^{1,2}$, Junliang Deng ${ }^{1,2}$, Yinglun $\mathrm{Li}^{1,2}$, Xun Wang ${ }^{1,2}$ and Ling Zhao ${ }^{1,2}$ \\ 1 College of Veterinary Medicine, Sichuan Agricultural University, Wenjiang, Chengdu 611130, China; \\ guohonrui@163.com (H.G.); lhuansy@163.com (H.L.); hongjun1ca@126.com (H.W.); \\ fangjing4109@163.com (J.F.); zzcj1@126.com (Z.Z.); dengj1213@126.com (J.D.); liyinglun01@163.com (Y.L.); \\ wangxun99@163.com (X.W.); lingzhao@sicau.edu.cn (L.Z.) \\ 2 Key Laboratory of Animal Diseases and Environmental Hazards of Sichuan Province, Sichuan Agriculture \\ University, Wenjiang, Chengdu 611130, China \\ 3 Key Laboratory of Agricultural information engineering of Sichuan Province, Sichuan Agriculture \\ University, Yaan 625014, Sichuan, China \\ * Correspondence: cui580420@sicau.edu.cn; Tel.: +86-13608264628; Fax: +86-0835-288-2510 \\ + These authors contributed equally to this work.
}

Received: 23 August 2019; Accepted: 20 September 2019; Published: 21 September 2019 updates

\begin{abstract}
Nickel (Ni) is known to be a major carcinogenic heavy metal. Occupational and environmental exposure to $\mathrm{Ni}$ has been implicated in human lung and nasal cancers. Currently, the molecular mechanisms of $\mathrm{Ni}$ carcinogenicity remain unclear, but studies have shown that $\mathrm{Ni}$-caused DNA damage is an important carcinogenic mechanism. Therefore, we conducted a literature search of DNA damage associated with $\mathrm{Ni}$ exposure and summarized known Ni-caused DNA damage effects. In vitro and vivo studies demonstrated that $\mathrm{Ni}$ can induce DNA damage through direct DNA binding and reactive oxygen species (ROS) stimulation. Ni can also repress the DNA damage repair systems, including direct reversal, nucleotide repair (NER), base excision repair (BER), mismatch repair (MMR), homologous-recombination repair (HR), and nonhomologous end-joining (NHEJ) repair pathways. The repression of DNA repair is through direct enzyme inhibition and the downregulation of DNA repair molecule expression. Up to now, the exact mechanisms of DNA damage caused by Ni and $\mathrm{Ni}$ compounds remain unclear. Revealing the mechanisms of DNA damage from Ni exposure may contribute to the development of preventive strategies in Ni carcinogenicity.
\end{abstract}

Keywords: Ni; carcinogenicity; DNA damage; ROS; DNA damage repair

\section{Introduction}

Nickel (Ni) is the 24 th most abundant element in Earth's crust [1]. On the one hand, at a low concentration, $\mathrm{Ni}$ is a nutritionally essential trace element for animals [2-4]. $\mathrm{Ni}$ is also a required trace element for several enzymes that play critical roles in energy and nitrogen metabolism [5]. On the other hand, at a high concentration, $\mathrm{Ni}$ is a toxic element [6-9]. The unique physical and chemical properties of Ni make it and its compounds suitable materials for many applications widely found in modern industries [1]. The widespread use of $\mathrm{Ni}$ increases its concentration in biogeochemical cycles and enhances human exposure to it and its compounds through environmental contamination and occupational exposure [10]. Human exposure to Ni occurs primarily via inhalation, ingestion, and dermal absorption [11]. In humans, Ni has been known to cause liver, kidney, spleen, brain, and tissue damage [12-14]. The International Agency for Research on Cancer (IARC) has classified Ni compounds such as nickel sulfate $\left(\mathrm{NiSO}_{4}\right)$, nickel oxide $(\mathrm{NiO})$, nickel hydroxides, and crystalline nickel as carcinogenic agents to humans (Group 1) [15]. 
It has been confirmed in many in vitro and vivo studies that $\mathrm{Ni}$ and $\mathrm{Ni}$ compounds have carcinogenicity [16-22]. Epidemiological studies presented that the probability of lung and nasal cancers are significantly increased in nickel-exposed workers [6]. Up to now, the exact mechanism of $\mathrm{Ni}$ carcinogenicity is still unclear, but it is clear that DNA damage is an important part of it [21,23-25]. After DNA damage occurs, cells activate several response signals, such as cell-cycle arrest, DNA repair, and cell death [26-28]. Numbers in in vitro and in vivo studies have presented that $\mathrm{Ni}$ and $\mathrm{Ni}$ compounds can induce DNA damage [29-33]. We also found that DNA oxidative damage and cell cycle arrest can be induced by dietary nickel chloride $\left(\mathrm{NiCl}_{2}\right)$ in excess of $300 \mathrm{mg} / \mathrm{kg}$ in the thymus, the bursa of Fabricius, the kidney, and the liver of broiler chickens [34-37]. If the DNA repair system cannot repair the damaged DNA, and the damaged DNA is passed onto the daughter DNA, this causes genomic instability, which finally promotes cancer development [38-41]. In this review, we paid attention to the effects of DNA damage and DNA repair system inhibition induced by Ni.

\section{Ni-Induced DNA Damage}

In general, several chemicals, radiation, and free radicals can affect the DNA and induce DNA damage [42]. The process of carcinogenesis is always initiated by the DNA damage [43], and damaged DNA replication may lead to gene mutation, which in turn induces protein alteration and cancer development [39,44-46].

In humans, DNA damage is very serious among Ni-smelting workers [47]. Previous studies found that $\mathrm{Ni}^{2+}$ can also induce DNA damage in various human cell systems, including human hepatocellular carcinoma (HepG2) [48], human TK6 [49], Chinese hamster lung fibroblast [50], A375 [51] and HCT-116 cells [52]. When human B lymphoblastoid cells were exposed to $\mathrm{NiCl}_{2}(0.63 \mathrm{mM})$ for 24 and $48 \mathrm{~h}$, cellular DNA damage was significantly increased when compared to the control cells [53]. A comet assay and $\gamma-\mathrm{H} 2 \mathrm{AX}$ immunofluorescence staining showed that nickel acetate-induced significant DNA damage in human colon-cancer cells (RKO) [54].

Animal studies have also shown that $\mathrm{Ni}$ or Ni compounds can cause DNA damage. In rats, comet-assay studies showed that single-strand breaks were observed in rat lungs and kidneys after acute treatment of animals with injected $\mathrm{NiCl}_{2}$ ( $44.4 \mathrm{mg} / \mathrm{kg}$ body weight), and the lung was the most susceptible tissue to $\mathrm{NiCl}_{2}$ [55]. Our studies have also indicated that dietary $\mathrm{NiCl}_{2}$ in excess of $300 \mathrm{mg} / \mathrm{kg}$ can induce DNA damage in the lung and the kidney of broiler chickens [56,57]. In addition, overexposure of nickel nitrate [ $\left.\mathrm{Ni}\left(\mathrm{NO}_{3}\right)_{2}\right]$ can induce DNA damage in earthworms (Eisenia foetida) [58], and $\mathrm{NiCl}_{2}$ can induce DNA damage in Caenorhabditis elegans [59].

\section{Binding of Ni to DNA and Nuclear Proteins in Ni-Induced DNA Damage}

Previous data have demonstrated that a portion of $\mathrm{Ni}$ ions can enter the nucleus after exposure to $\mathrm{Ni}$ and $\mathrm{Ni}$ compounds [60,61]. Fletcher et al. [62] found that exposure of cells to water-soluble Ni salts resulted in very low nuclear but high cytosolic Ni levels, while exposure to insoluble Ni salts caused relatively high nuclear levels. It has also been confirmed that $\mathrm{Ni}$ ions exhibit a lower binding affinity for DNA, thus most nickel ions in the cell nucleus could interact with the histone [63-67]. Oliveria et al. [68] clearly demonstrated that $\mathrm{Ni}^{2+}$ interacts by binding to dsDNA strands causing conformational changes. The interaction of DNA with Ni has been extensively investigated since they are involved in processes leading to DNA damage [68]. Ciccarelli et al. [69] demonstrated the presence of Ni-nucleic acid histone complexes in Ni-treated rats and suggested that Ni may initiate DNA damage by forming this complex. Binding of Ni to chromatin DNA and associated proteins has been reported to cause DNA damage, which consists of DNA single-strand breaks and DNA intrastrand cross-linking [70,71]. In recent decades, coordination compounds with $\mathrm{Ni}$ have become quite important in medicinal chemistry, and their research data show that $\mathrm{Ni}(\mathrm{II})$ complexes can wind DNA strands through groove interactions and promote strand breakage [71]. 


\section{Reactive Oxygen Species (ROS) in Ni-Induced DNA Damage}

ROS are a group of short-lived, highly reactive, oxygen-containing molecules [72]. ROS play an important role in cancer development [73]. Excessive ROS attack the DNA, which then results in genomic instability that is a promoter of tumorigenesis [72]. Genomic instability has been suggested to be a major driving force of oncogenesis and can account for genetic diversity in many cancers [72]. It has been shown that oxidative stress is the basic toxicological mechanism of Ni overexposure [33,51,74,75]. $\mathrm{Ni}$ and $\mathrm{Ni}$ compounds increase ROS accumulation through both a direct increase in ROS generation and an antioxidant-system suppression, which then damages the DNA (as shown in Figure 1).

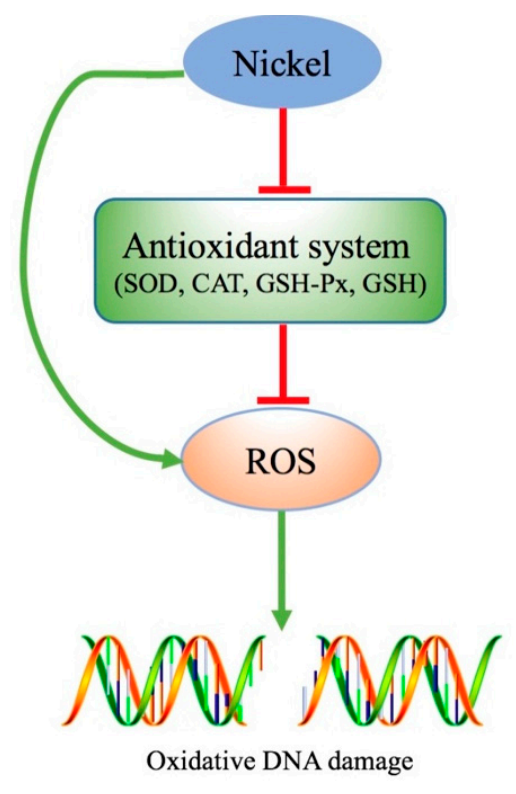

Figure 1. Ni induced reactive oxygen species (ROS) accumulation. Excessive exposure of Ni can increase ROS accumulation through directly increasing ROS generation and through an antioxidant system suppression, which then damages the DNA.

\subsection{Ni-Induced ROS Accumulation}

Numerous in vitro and in vivo studies have shown that $\mathrm{Ni}$ and $\mathrm{Ni}$ compounds can induce ROS accumulation and oxidative stress [76-83]. Ni and Ni compounds induce ROS accumulation in two ways: (i) increasing ROS generation and (ii) impairing the antioxidant system $[84,85]$. Our previous data indicated that dietary $\mathrm{NiCl}_{2}$ in excess of $300 \mathrm{mg} / \mathrm{kg}$ can suppress the activities of antioxidant enzymes such as superoxide dismutase (SOD), catalase (CAT), and glutathione peroxidase (GSH-Px), and glutathione (GSH) contents in kidney, lung, thymus, spleen, bursa of Fabricius, intestine, and cecal tonsil [56,57,86-90]. Ni nanoparticles (NiNPs) $(45 \mathrm{mg} / \mathrm{kg}$ ) treatment for 10 weeks increased ROS generation and decreased SOD, CAT activities, and GSH contents in rat testes [76]. Ahamed et al. also reported that culturing with $25-100 \mu \mathrm{g} / \mathrm{mL}$ nickel oxide nanoparticles (NiONPs) for $24 \mathrm{~h}$ can promote ROS accumulation in human hepatocytes (HepG2), and NiONPs caused cytotoxicity mainly via ROS [91]. ROS play a critical role in Ni-induced apoptosis and DNA damage [92-96]. Ni exposure can generate ROS in exposed cells, and ROS generation mediates biological effects in nickel-treated cells, which may play a role in nickel-induced carcinogenesis. ROS production is a critical factor in $\mathrm{Ni}$ toxicity and is also an indispensable element in Ni carcinogenesis [97-99].

\subsection{ROS-Dependent Ni-Induced DNA Damage}

Excessive ROS can directly attack the DNA by oxidizing nucleoside bases, producing modified nucleotides (8-hydroxy-2'-deoxyguanosine, 8-OHdG) [100-102]. The elevated 8-OHdG level is regarded as an indicator of DNA oxidative damage [103]. It has been suggested that synergistic DNA damage 
induced by simultaneous exposure of $\mathrm{Ni}$ compounds is possibly related to ROS [53,104,105]. Several in vitro and in vivo studies have demonstrated that $\mathrm{Ni}$ and $\mathrm{Ni}$ compounds can increase DNA oxidative damage marker levels (8-OHdG) [106-111]. In vivo, our previous studies showed that dietary $\mathrm{NiCl}_{2}$ in excess of $300 \mathrm{mg} / \mathrm{kg}$ inhibits the antioxidant system, which leads to an increase in DNA oxidative damage markers, e.g., 8-OHdG contents in the lung and the kidney [56,57]. Liu et al. found that treatment with $\mathrm{NiSO}_{4}(20 \mathrm{mg} / \mathrm{kg})$ for 20 days induced ROS accumulation and increased 8-OHdG levels in mouse livers [107]. Treatment of cultured HeLa cells with $\mathrm{Ni}_{3} \mathrm{~S}_{2}(10 \mu \mathrm{g} / \mathrm{mL})$ can largely increase 8-OHdG contents, whereas $\mathrm{NiO}$ (black), $\mathrm{NiO}$ (green), and $\mathrm{NiSO}_{4}$ do not enhance the production of 8-OHdG [111]. $\mathrm{NiCl}_{2}(0.125,0.25$, and $0.5 \mathrm{mM})$ treatment for $24 \mathrm{~h}$ can also induce mitochondrial DNA (mtDNA) damage, including increased mitochondrial 8-OHdG contents and reduced mtDNA contents and mtDNA transcript levels in Neuro2a cells [112]. In recent decades, several studies have reported that $\mathrm{Ni}$ and $\mathrm{Ni}$ compounds nanoparticles of can also induce DNA damage [113-118]. Mo et al. [113] reported that oxidative DNA damage was significantly upregulated in the lungs of mice after being intratracheally instilled with $50 \mu \mathrm{g}$ Nano-Ni. In vitro, Abudayyak et al. reported that NiO NPs induced excessive ROS generation and then caused DNA oxidative damage (8-OHdG up-regulation) in NRK-52E kidney epithelial cells and SH-SY5Y neuronal cells [114,115]. It has been also shown that $\mathrm{Ni}$ and $\mathrm{NiO}$ NPs at higher doses $(25$ and $50 \mathrm{ug} / \mathrm{mL}$ ) can induce DNA strand breaks, and an increase in the DNA strand breaks is due to intracellular ROS generation [119].

Through co-treatment with the antioxidant N-acetylcysteine (NAC) and NiNPs, NAC can mitigate NiNPs-induced ROS generation and DNA strand breaks, suggesting the potential mechanism of ROS in DNA damage [120]. Ni acetate can increase intracellular ROS generation and DNA strand breaks in Nrf2 knockdown cells, indicating that ROS play an important role in Ni-induced DNA damage [54].

\subsection{ROS-Independent Ni-Induced DNA Damage}

In contrast to most studies, Kumar et al. demonstrated that $\mathrm{NiSO}_{4}$ affected DNA replication and damaged DNA but did not induce any detectable ROS production in Escherichia coli, concluding that Ni-induced DNA damage is through an ROS-independent pathway [121]. They also demonstrated that $\mathrm{Ni}$ exposure specifically affected DNA polymerization and thereby induced DNA damage. A major reason for the differing results may be related to differences between mammals and bacteria.

\section{Interference of Ni with DNA Damage Repair Systems}

After DNA damage occurs, specific pathways are activated to facilitate the identification of the damaged regions and their repair [122]. The DNA repair system contributes to the maintenance of the genetic sequence, the correction of DNA damage, and genomic instability [123,124].

Some studies showed that $\mathrm{Ni}$ can inhibit the DNA repair function and promote carcinogenesis [121,125-129]. Arita et al. reported that 29 DNA repair genes were repressed, and two DNA repair genes were overexpressed in the isolated peripheral blood mononuclear cells (PBMC) in Ni-refinery workers [130]. In addition, Scalon et al. [129] reported that DNA double-strand breaks were significantly higher in the $\mathrm{NiCl}_{2}\left(250\right.$ and $500 \mu \mathrm{M}, 48 \mathrm{~h}$ ) treatment cells than non- $\mathrm{NiCl}_{2}$ treatment cells after ionizing radiation (IR) exposure. Likewise, Ni also causes DNA damage repair-system repression, which results in damaged DNA not being removed. The accumulation of DNA lesions facilitates the process of tumorigenesis [131]. At present, an increasing number of studies indicate that DNA repair suppression is a non-ignorable mechanism of oncogenesis [43,132,133].

In general, the DNA repair system can always fix and clear damaged DNA that is induced by normal metabolic activities and environmental factors [134]. Recently, the DNA repair mechanism was found to contain direct reversal, nucleotide repair (NER), base excision repair (BER), mismatch repair (MMR), and double strand break repair including homologous recombination repair (HR) and nonhomologous end joining (NHEJ) repair $[135,136]$, as shown in Figure 2. Next, we review the effect of Ni on every DNA damage-repair pathway (Table 1). 


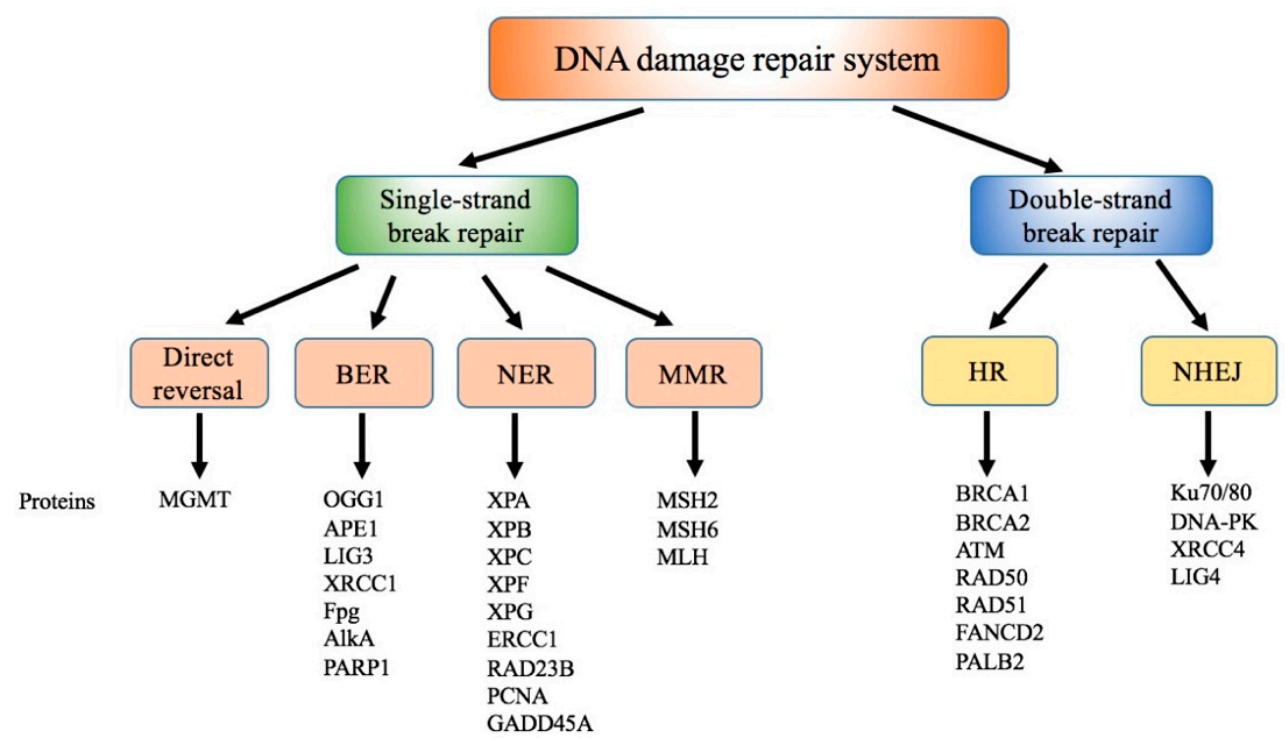

Figure 2. DNA damage repair systems. DNA damage repair systems include direct reversal, base-excision repair (BER), nucleotide repair (NER), mismatch repair (MMR), homologousrecombination repair (HR), and nonhomologous end joining (NHEJ) repair pathways.

Table 1. Effect of Ni on DNA damage-repair systems.

\begin{tabular}{|c|c|c|c|}
\hline Item & Suppression & Enhancement & No Alteration \\
\hline Direct reversal & $\begin{array}{c}\text { Ji et al. [137], Iwitzki et al. [138], Chen et al. } \\
\text { [139], Chervona et al. [140] }\end{array}$ & & \\
\hline BER & Wu et al. [47], Wozniak and Blasiak [141] & & \\
\hline & Hartwig et al. [127], Hu et al. [142], & & \\
\hline NER & $\begin{array}{c}\text { Lee-Chen et al. [143], Wozniak et al. [144], [145], } \\
\text { Hartmann and Hartwig [146], } \\
\text { Hartwig et al. [128], Hu et al. [125], Wozniak } \\
\text { and Blasiak [25], Kim et al. [147] }\end{array}$ & & \\
\hline MMR & Scanlon et al. [129] & & Ji et al. [137] \\
\hline HR & Scanlon et al. [129] & & \\
\hline NHEJ & Morales et al. [148] & & Scanlon et al. [129] \\
\hline
\end{tabular}

\subsection{Effect of Ni on Direct Reversal}

For reversible DNA damage, our body first uses the direct-reversal repair mechanism to correct damaged bases [149]. The basic means of DNA repair way is direct reversal, which corrects damaged DNA with DNA alkylating agents [149]. $\mathrm{O}^{6}$-methylguanine DNA methyltransferase (MGMT) and ALKBH $\alpha$-ketoglutarate Fe(II) dioxygenases (FeKGDs) are the main direct reversal repair proteins [150].

In nickel sulfide (NiS)-treated or NiS-transformed human 16HBE cells, the DNA repair gene MGMT mRNA and protein-expression levels are significantly reduced, suggesting that the downregulation of MGMT expression levels may be an early event involved in NiS-induced cell transformation [137]. MGMT is unique among DNA repair proteins because it acts alone to remove DNA adducts [151]. MGMT repair can remove both methyl and ethyl adducts, and this reaction is a nonenzymatic (stoichiometric) reaction. Previous studies confirmed that MGMT overexpression can increase the resistance to cancer. MGMT silencing is also associated with DNA hypermethylation, histone modifications, and DNA methyltransferase 1 (DNMT1) upregulation [137]. However, Iwitzki et al. found that Ni treatment does not affect the MGMT protein levels and only inhibits the MGMT activity in Chinese hamster ovary cells (CHO) cells [138]. These differences are possibly due to the different cell types under study or the differences in duration of Ni exposure.

The other type of direct-reversal repair is performed by ALKBH proteins that are members of a superfamily of FeKGDs [152]. Only four ALKBH family proteins (ALKBH1-3 and FTO) have the ability of DNA alkyl damage removal [153]. Ni can also directly inhibit the DNA alkylation repair 
enzymes, e.g., ALKBH2 and ALKBH3, by replacing iron at the catalytic site and then reducing the direct reversal of DNA damage $[139,140]$.

\subsection{Effect of Ni on BER}

BER mainly repairs oxidative DNA damage, and it can excise and replace a single damaged nucleotide base [154]. The process of BER has two steps. First, DNA glycosylase finds and cuts the damaged DNA base. Second, the DNA repair proteins repair the damaged site [154]. At least 11 distinct mammalian DNA glycosylases are known, such as 8-oxoguanine DNA glycosylase (OGG1), AP endonuclease (APE1), DNA ligase 1 (LIG1), LIG3, and X-ray repair cross-complementing protein 1 (XRCC1) [122,155].

In a nickel smelting worker's serum, the oxidative DNA damage marker (8-OHdG) levels are significantly increased, and BER DNA glycosylase human OGG1 (hOGG1) is significantly lower than that of nonexposed workers [47]. hOGG1 is a single BER enzyme, specifically recognizing and repairing DNA oxidative damage by removing 7,8-dihydro-8-oxoguanine (8-oxoG). Downregulation of hOGG1 expression is associated with aging, neurodegenerative disorders, and cancer [155,156]. Additionally, Ni at $1 \mu \mathrm{M}$ can inhibit the activity of formamidopyrimidine-DNA glycosylase (Fpg) and 3-methyladenine-DNA glycosylase II (Alk A), which are involved in DNA excision repair [141]. Fpg is a glycosylase-initiating BER enzyme in E. coli and participates in the first step of the BER to remove specific modified bases from the DNA.

\subsection{Effect of Ni on NER}

The aim of NER is to repair DNA damage that has two or more base-impair sites [157,158]. The process of NER entails damaged-site recognition, damaged-strand removal, and DNA ligation [159-162]. The NER process needs the participation of many proteins, such as Xeroderma pigmentosum (XP) complementation Groups A through G, excision repair cross-complementation group 1 (ERCC1), and proliferating cell nuclear antigen (PCNA) [163,164].

The NER pathway plays an important role in the prevention of cancer formation, such as bladder cancer and lung cancer [165]. It has been shown that Ni inhibits the removal of UV-induced DNA damage by disturbing DNA repair proteins and affecting the NER process $[127,142-144]$. Hartwig et al. showed that Ni inhibits NER through the disruption of the incision step in HepG2 and CHO cells [127,145]. The preferential binding of $\mathrm{Ni}(\mathrm{II})$ to the protein (DNA repair enzyme) fraction, as compared to DNA and RNA fractions, is the reason for NER incision-step inhibition [146]. Ni also inhibits the NER incision step, possibly through direct interaction with zinc finger repair enzymes such as XPA and poly ADP-ribose polymerase (PARP), and the displacement of the zinc ions [125-128,131,144,166].

Kim et al. [147] found that treatment with nickel acetate $20 \mu \mathrm{M}$ for $24 \mathrm{~h}$ can induce p53-mediated NER DNA repair-pathway suppression, which is a promoter of tumor development. Nickel acetate inhibits p53 transcriptional activity and then suppresses DNA-damage-inducible protein 45 alpha (GADD45A) expression. Typically, the GADD45A, PCNA, and XPG complex works in the NER incision process, and the function of this complex is site $3^{\prime}$ of damage cleavage [167]. Downregulation of GADD45A expression levels results in GADD45A, PCNA, and XPG complex inhibition, which then impairs the GADD45A-mediated NER mechanism [147].

\subsection{Effect of Ni on MMR}

DNA MMR is also a critical pathway for DNA damage. The MMR system maintains genomic stability by repairing base-base mismatches and insertion/deletion loops that arise from DNA replication, thereby preventing mutations from becoming permanent in dividing cells [168,169]. Defects in MMR increase the spontaneous mutation rate and sporadic human cancers [170,171]. MMR is a complex reaction involving multiple proteins that recognize a mismatched base, excise the DNA damage, and resynthesize the DNA sequence containing the correct base and using the parental strand as a template [172]. In general, MMR is initiated when highly conserved proteins (MutS homolog 
2 MSH2 and MSH6) recognize single base mismatches [173]. In cases of insertion/deletions loops with two or more extra bases, MSH2 and MSH3 are responsible for detection. Following recognition, one of the mutL homolog (MLH) heterodimers binds to the mismatch, and PCNA is loaded onto the DNA by replicating factor $C$, activating MLH to incise the nascent strand and removing the error in an ATP-dependent manner [174,175]. Then, DNA polymerase synthetizes the new strand followed by nick-sealing [176,177].

Scanlon et al. found that treatment with $\mathrm{NiCl}_{2} 250$ and $500 \mu \mathrm{M}$ for $48 \mathrm{~h}$ could decrease MMR MLH1 protein and mRNA expression levels in tumorigenic (A549) and nontumorigenic (BEAS-2B) human lung cells [129], and that $\mathrm{NiCl}_{2}$ could directly bind to the MLH1 gene promoter and then reduce its activity of it. However, it has been demonstrated that there are no alterations of DNA repair genes including hMLH1 and hMSH6 in NiS-transformed 16HBE cells [137].

\subsection{Effect of Ni on Double-Strand Breaks Repair Pathways}

Double-strand breaks (DSB), a DNA damage type, causes changes to the DNA sequence [178]. After DSB occur, repair systems NHEJ or HR are activated [179]. HR, a conservative process, fixes the damaged DNA to be the same as the original DNA sequence. In this process, the damaged DNA sequence is removed, and the new DNA synthesis is according to the homologous sister chromatid [180]. The proteins involved in the HR are shown in Figure 2, including breast cancer 1 (BRCA1), BRCA2, RAD51 (human homolog of Saccharomyces cerevisiae RAD50), fanconi anemia group D2 protein (FANCD2), and partner and localizer of BRCA2 (PALB2) genes [180,181].

In mammalian cells, NHEJ is a preferential way to repair DSB because a homologous template is not necessarily needed in NHEJ rejoins [182]. In NHEJ, the Ku70/Ku80 heterodimer recognizes and binds the two ends of the broken DNA strands [183]. Multiple enzymes are involved in the rejoining process, including LIG4, X-ray repair cross complementing 4 (XRCC4), and DNA-dependent protein kinase (DNA-PK) [183]. LIG4, XRCC4, and DNA-PK heterodimers are recruited by the Ku70/Ku80 heterodimer to the damage site promoting the ligation of the two ends [182].

Takahashi et al. [184] reported that treatment with $40 \mathrm{mM}$ or more of $\mathrm{NiCl}_{2}$ for $30 \mathrm{~min}$ could inhibit the repair of DNA double-strand breaks in Chinese hamster ovary cells. $\mathrm{NiCl}_{2}$ also inhibited DNA repair only at cytotoxic concentrations at which the cells lost their proliferative ability. Scanlon et al. found that $\mathrm{NiCl}_{2}$ (250 and $500 \mu \mathrm{M}$ for $48 \mathrm{~h}$ ) exposure led to the downregulation of HR without downregulation of NHEJ repair, and that $\mathrm{NiCl}_{2}$ decreased the HR proteins (BRCA1, RAD51, and FANCD2) and the mRNA expression levels in tumorigenic (A549) and nontumorigenic (BEAS-2B) human lung cells [129]. There were no changes in the NHEJ repair proteins (DNA-PK, KU80, XRCC4, LIG4 protein, and mRNA expression levels) in tumorigenic (A549) and non-tumorigenic (BEAS-2B) human lung cells [129]. The mechanism of the $\mathrm{NiCl}_{2}$-inhibited HR pathway is through the transcriptional repression of DNA repair proteins. After evaluating the DSB DNA repair pathway by the ex vivo GFP reporter assay system, Morales et al. found that $\mathrm{NiCl}_{2}$ at low doses $(100 \mu \mathrm{M})$ activated the HR pathway but did not affect the NHEJ repair pathway [148]. In contrast, the highest tested dose of $\mathrm{NiCl}_{2}(500 \mu \mathrm{M})$ significantly inhibited the HR and the NHEJ repair pathways in U2OS cells [148]. The different results of Morales et al. and Scanlon et al. on the $\mathrm{NiCl}_{2}$-affected NHEJ repair pathway may be because of $\mathrm{NiCl}_{2}$ treatment concentration or the cell model.

\subsection{Others}

When bacterial DNA encounters heavy doses of DNA-damaging agents, it activates the special DNA repair-system SOS response [185]. In general, SOS response repairs the damaged DNA and ensures the process of DNA replication [186]. If the SOS response is suppressed, the evolution of bacterial resistance and pathogens is prevented more easily [187]. Kumar et al. [121] reported that exposure to $1 \mathrm{M} \mathrm{Ni}$ ions for $15 \mathrm{~h}$ induced double-strand breaks of E. coli. In DNA, meanwhile, the SOS response is impaired by RecBCD function blockage. 


\section{Conclusions and Future Perspectives}

There have been many studies on the molecular mechanism of $\mathrm{Ni}$ and $\mathrm{Ni}$ compounds-induced DNA damage associated with carcinogenesis. However, the exact mechanisms of DNA damage caused by $\mathrm{Ni}$ and $\mathrm{Ni}$ compounds are still unclear. Previous studies have demonstrated that Ni can induce DNA damage, and that Ni-induced DNA damage is mainly through ROS generation. Ni can also directly bind DNA and induce DNA damage. Meanwhile, Ni can also repress the DNA damage-repair systems, including DNA direct-reversal, NER, BER, HDR, MMR, and NHEJ repair pathways, which increases the accumulation of the damaged DNA bases. The repression of DNA repair is through impacting cellular DNA repair on multiple levels, from direct enzyme inhibition to the modulation of DNA repair-molecule expression (Figure 3). Ni exposure can therefore directly induce cancer through DNA damage and DNA damage-repair inhibition. On the other hand, DNA damage-repair inhibition induced by $\mathrm{Ni}$ can also increase the risk of other agents (ultraviolet light, ionizing radiation, chemicals, etc.) promoting caner. Ni-induced DNA repair pathway suppression results in damaged DNA accumulation in the cells. If the damaged DNA cell can survive, the damaged DNA is passed down through the damage site to daughter cells, which thus contributes to potential carcinogenesis.

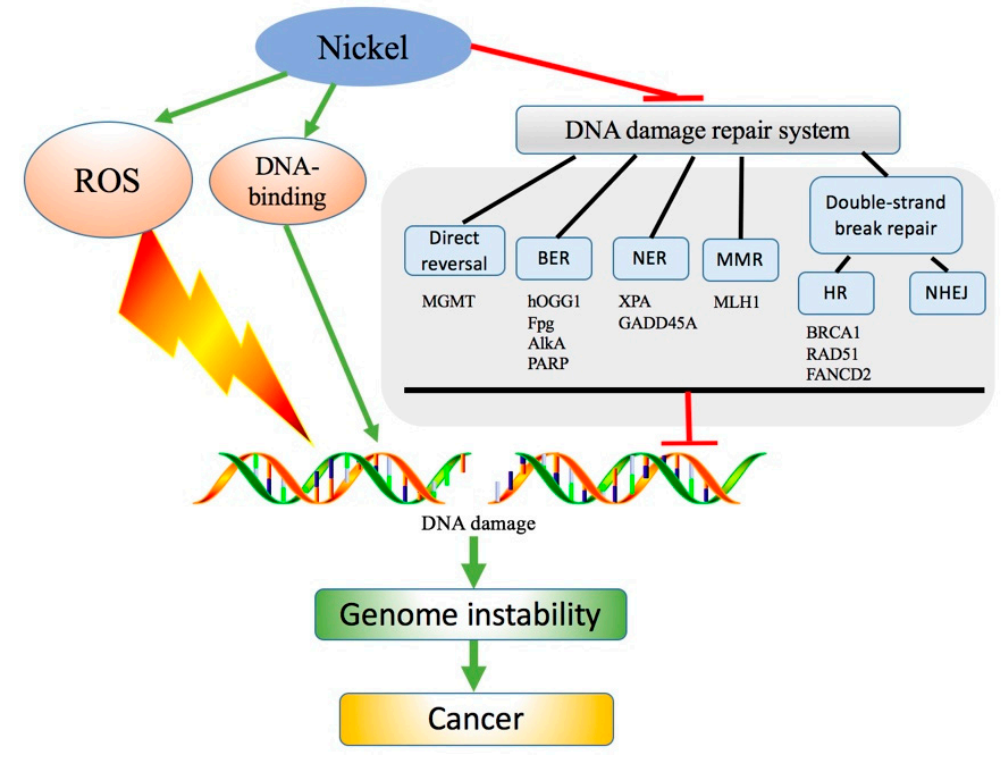

Figure 3. Simplified scheme of Ni-induced DNA damage in cancer occurrence. Excessive exposure to Ni can induce DNA damage, mainly through direct DNA binding and ROS generation. Ni can also repress the DNA damage-repair pathways, including direct reversal, BER, NER, MMR, HR, and NHEJ repair. DNA damage causes genome instability that may ultimately contribute to cancer occurrence.

An increasing number of studies confirm that ROS generation is a basis mechanism of Ni toxicity [6]. However, there are no studies about the ROS generation in Ni-induced DNA damage repair inhibition. In the next study, we need more research to explore whether ROS are also essential or just participates in Ni-induced DNA damage-repair pathway inhibition in the carcinogenesis.

Author Contributions: H.G., H.L., H.W. and H.C. designed and wrote the paper. J.F., Z.Z., J.D., Y.L., X.W., and L.Z. checked and revised it.

Funding: This research was supported by the program for Changjiang scholars and the university innovative research team (IRT 0848), and the Shuangzhi project of Sichuan Agricultural University (03572437; 03573050).

Conflicts of Interest: The authors declare that there are no conflicts of interest. 


\section{Abbreviations}

\begin{tabular}{|c|c|}
\hline ROS & reactive oxygen species \\
\hline NER & nucleotide repair \\
\hline BER & base excision repair \\
\hline MMR & mismatch repair \\
\hline HR & homologous recombination repair \\
\hline NHEJ & non-homologous end joining \\
\hline ER & endoplasmic reticulum \\
\hline SOD & superoxide dismutase \\
\hline CAT & catalase \\
\hline GSH-Px & glutathione peroxidase \\
\hline GSH & glutathione \\
\hline 8-OHdG & 8-hydroxy-2'-deoxyguanosine \\
\hline MNNG & N-methyl-N'-nitro-N-nitrosoguanidine \\
\hline MNU & N-methyl-N-nitrosourea \\
\hline MMS & methyl methanesulfonate \\
\hline MGMT & $\mathrm{O}^{6}$-Methylguanine DNA methyltransferase \\
\hline FeKGDs & ALKBH $\alpha$-ketoglutarate Fe(II) dioxygenases \\
\hline $\mathrm{NiS}$ & nickel sulfide \\
\hline DNMT1 & DNA methyltransferase 1 \\
\hline OGG1 & 8-oxoguanine DNA glycosylase \\
\hline APE1 & AP endonuclease \\
\hline LIG1 & DNA ligase 1 \\
\hline XRCC1 & X-ray repair cross-complementing protein 1 \\
\hline Fpg & formamidopyrimidine-DNA glycosylase \\
\hline AlkA & 3-methyladenine-DNA glycosylase II \\
\hline $\mathrm{XP}$ & xeroderma pigmentosum \\
\hline ERCC1 & excision repair cross-complementation group 1 \\
\hline PCNA & proliferating cell nuclear antigen \\
\hline PARP & poly ADP-ribose polymerase \\
\hline GADD45A & DNA-damage-inducible protein 45 alpha \\
\hline MLH & mutL homolog \\
\hline DSB & double-strand breaks \\
\hline BRCA1 & breast cancer 1 \\
\hline RAD51 & human homolog of S. cerevisiae RAD50 \\
\hline f FANCD2 & anconi anemia group $\mathrm{D} 2$ protein \\
\hline PALB2 & partner and localizer of BRCA2 \\
\hline $\mathrm{XRCC} 4$ & X-ray repair cross complementing 4 \\
\hline DNA-PK & DNA-dependent protein kinase \\
\hline $\mathrm{CHO}$ & Chinese hamster ovary cells \\
\hline
\end{tabular}

\section{References}

1. Zambelli, B.; Uversky, V.N.; Ciurli, S. Nickel impact on human health: An intrinsic disorder perspective. Biochim. Biophys. Acta 2016, 1864, 1714-1731. [CrossRef] [PubMed]

2. Zdrojewicz, Z.; Popowicz, E.; Winiarski, J. Nickel-role in human organism and toxic effects. Pol. Merkur. Lek. 2016, 41, 115-118.

3. Zambelli, B.; Ciurli, S. Nickel and human health. Met. Ions Life Sci. 2013, 13, 321-357. [PubMed]

4. Afridi, H.I.; Talpur, F.N.; Kazi, T.G.; Brabazon, D. Estimation of aluminum, arsenic, lead and nickel status in the samples of different cigarettes and their effect on human health of irish smoker hypertensive consumers. Clin. Lab. 2015, 61, 1147-1156. [CrossRef] [PubMed]

5. Boer, J.L.; Mulrooney, S.B.; Hausinger, R.P. Nickel-dependent metalloenzymes. Arch. Biochem. Biophys. 2014, 544, 142-152. [CrossRef] [PubMed] 
6. Das, K.K.; Reddy, R.C.; Bagoji, I.B.; Das, S.; Bagali, S.; Mullur, L.; Khodnapur, J.P.; Biradar, M.S. Primary concept of nickel toxicity-An overview. J. Basic Clin. Physiol. Pharmacol. 2018, 30, 141-152. [CrossRef] [PubMed]

7. Saito, M.; Arakaki, R.; Yamada, A.; Tsunematsu, T.; Kudo, Y.; Ishimaru, N. Molecular mechanisms of nickel allergy. Int. J. Mol. Sci. 2016, 17, 202. [CrossRef] [PubMed]

8. Dukes, M.P.; Rowe, R.K.; Harvey, T.; Rangel, W.; Pedigo, S. Nickel reduces calcium dependent dimerization in neural cadherin Electronic supplementary information (ESI) available. Metallomics 2019, 11, 475-482. [CrossRef] [PubMed]

9. Shahzad, B.; Tanveer, M.; Rehman, A.; Cheema, S.A.; Fahad, S.; Rehman, S.; Sharma, A. Nickel; whether toxic or essential for plants and environment-A review. Plant Physiol. Biochem. 2018, 132, 641-651. [CrossRef] [PubMed]

10. Doll, R. Nickel exposure: A human health hazard. IARC Sci. Publ. 1984, 53, 3-21.

11. Zeinali, T.; Salmani, F.; Naseri, K. Dietary intake of cadmium, chromium, copper, nickel, and lead through the consumption of meat, liver, and kidney and assessment of human health risk in birjand, southeast of Iran. Biol. Trace Elem. Res. 2019, 191, 338-347. [CrossRef] [PubMed]

12. Das, K.K.; Das, S.N.; Dhundasi, S.A. Nickel, its adverse health effects \& oxidative stress. Indian J. Med. Res. 2008, 128, 412-425. [PubMed]

13. Shi, Z. Nickel carbonyl: Toxicity and human health. Sci. Total Environ. 1994, 148, 293-298. [CrossRef]

14. Haber, L.T.; Erdreicht, L.; Diamond, G.L.; Maier, A.M.; Ratney, R.; Zhao, Q.; Dourson, M.L. Hazard identification and dose response of inhaled nickel-soluble salts. Regul. Toxicol. Pharmacol. 2000, 31, 210-230. [CrossRef] [PubMed]

15. Bolek, E.C.; Erden, A.; Kulekci, C.; Kalyoncu, U.; Karadag, O. Rare occupational cause of nasal septum perforation: Nickel exposure. Int. J. Occup. Med. Environ. Health 2017, 30, 963-967. [CrossRef] [PubMed]

16. Salnikow, K.; Zhitkovich, A. Genetic and epigenetic mechanisms in metal carcinogenesis and cocarcinogenesis: Nickel, arsenic, and chromium. Chem. Res. Toxicol. 2008, 21, 28-44. [CrossRef] [PubMed]

17. Xu, Z.G.; Ren, T.; Xiao, C.Y.; Li, H.Y.; Wu, T.C. Nickel promotes the invasive potential of human lung cancer cells via TLR4/MyD88 signaling. Toxicology 2011, 285, 25-30. [CrossRef] [PubMed]

18. Beyersmann, D.; Hartwig, A. Carcinogenic metal compounds: Recent insight into molecular and cellular mechanisms. Arch. Toxicol. 2008, 82, 493-512. [CrossRef]

19. Denkhaus, E.; Salnikow, K. Nickel essentiality, toxicity, and carcinogenicity. Crit. Rev. Oncol. Hematol. 2002, 42, 35-56. [CrossRef]

20. Henderson, R.G.; Durando, J.; Oller, A.R.; Merkel, D.J.; Marone, P.A.; Bates, H.K. Acute oral toxicity of nickel compounds. Regul. Toxicol. Pharmacol. 2012, 62, 425-432. [CrossRef]

21. Coogan, T.P.; Latta, D.M.; Snow, E.T.; Costa, M. Toxicity and carcinogenicity of nickel compounds. Crit. Rev. Toxicol. 1989, 19, 341-384. [CrossRef] [PubMed]

22. Sunderman, F.W., Jr. Carcinogenicity of nickel compounds in animals. IARC Sci. Publ. 1984, 53, 127-142.

23. Costa, M.; Davidson, T.L.; Chen, H.; Ke, Q.; Zhang, P.; Yan, Y.; Huang, C.; Kluz, T. Nickel carcinogenesis: Epigenetics and hypoxia signaling. Mutat. Res. 2005, 592, 79-88. [CrossRef] [PubMed]

24. Savolainen, H. Biochemical and clinical aspects of nickel toxicity. Rev. Environ. Health 1996, 11, 167-173. [CrossRef] [PubMed]

25. Wozniak, K.; Blasiak, J. Free radicals-mediated induction of oxidized DNA bases and DNA-protein cross-links by nickel chloride. Mutat. Res. 2002, 514, 233-243. [CrossRef]

26. Khanna, K.K.; Jackson, S.P. DNA double-strand breaks: Signaling, repair and the cancer connection. Nat. Genet. 2001, 27, 247-254. [CrossRef]

27. Zhou, B.B.S.; Elledge, S.J. The DNA damage response: Putting checkpoints in perspective. Nature 2000, 408, 433-439. [CrossRef] [PubMed]

28. Tubbs, A.; Nussenzweig, A. Endogenous DNA damage as a source of genomic instability in cancer. Cell 2017, 168, 644-656. [CrossRef] [PubMed]

29. Jia, J.; Chen, J. Chronic nickel-induced DNA damage and cell death: The protection role of ascorbic acid. Environ. Toxicol. 2008, 23, 401-406. [CrossRef]

30. Magaye, R.; Zhao, J.S. Recent progress in studies of metallic nickel and nickel-based nanoparticles' genotoxicity and carcinogenicity. Environ. Toxicol. Pharmacol. 2012, 34, 644-650. [CrossRef] 
31. Joyner, J.C.; Reichfield, J.; Cowan, J.A. Factors influencing the DNA nuclease activity of iron, cobalt, nickel, and copper chelates. J. Am. Chem. Soc. 2011, 133, 15613-15626. [CrossRef] [PubMed]

32. Dumala, N.; Mangalampalli, B.; Chinde, S.; Kumari, S.I.; Mahoob, M.; Rahman, M.F.; Grover, P. Genotoxicity study of nickel oxide nanoparticles in female Wistar rats after acute oral exposure. Mutagenesis 2017, 32, 417-427. [CrossRef] [PubMed]

33. Doreswamy, K.; Shrilatha, B.; Rajeshkumar, T. Nickel-induced oxidative stress in testis of mice: Evidence of DNA damage and genotoxic effects. J. Androl. 2004, 25, 996-1003. [CrossRef] [PubMed]

34. Tang, K.; Guo, H.; Deng, J.; Cui, H.; Peng, X.; Fang, J.; Zuo, Z.; Wang, X.; Wu, B.; Li, J.; et al. Inhibitive effects of nickel chloride (NiCl(2)) on thymocytes. Biol. Trace Elem. Res. 2015, 164, 242-252. [CrossRef] [PubMed]

35. Yin, S.; Cui, H.; Peng, X.; Fang, J.; Zuo, Z.; Deng, J.; Wang, X.; Wu, B.; Guo, H. Toxic effect of NiCl2 on development of the bursa of Fabricius in broiler chickens. Oncotarget 2016, 7, 125-139. [PubMed]

36. Guo, H.; Cui, H.; Peng, X.; Fang, J.; Zuo, Z.; Deng, J.; Wang, X.; Wu, B.; Chen, K.; Deng, J. Dietary $\mathrm{NiCl}_{2}$ causes $\mathrm{G}_{2} / \mathrm{M}$ cell cycle arrest in the broiler's kidney. Oncotarget 2015, 6, 35964-35977. [CrossRef] [PubMed]

37. Guo, H.R.; Cui, H.M.; Fang, J.; Zuo, Z.C.; Deng, J.L.; Wang, X.; Zhao, L.; Chen, K.J.; Deng, J. Nickel chloride $(\mathrm{NiCl})$ in hepatic toxicity: Apoptosis, G2/M cell cycle arrest and inflammatory response. Aging 2016, 8, 3009-3027. [CrossRef]

38. Hosoya, N.; Miyagawa, K. Targeting DNA damage response in cancer therapy. Cancer Sci. 2014, 105, 370-388. [CrossRef]

39. Lord, C.J.; Ashworth, A. The DNA damage response and cancer therapy. Nature 2012, 481, 287-294. [CrossRef]

40. Jackson, S.P. The DNA-damage response: New molecular insights and new approaches to cancer therapy. Biochem. Soc. Trans. 2009, 37, 483-494. [CrossRef]

41. Roos, W.P.; Thomas, A.D.; Kaina, B. DNA damage and the balance between survival and death in cancer biology. Nat. Rev. Cancer 2016, 16, 20-33. [CrossRef] [PubMed]

42. Hoeijmakers, J.H.J. The key role of DNA damage on cancer, aging and longevity. Environ. Mol. Mutagenesis 2012, 53, S13.

43. Schiewer, M.J.; Knudsen, K.E. DNA damage response in prostate cancer. CSH Perspect. Med. 2019, 9, a030486. [CrossRef] [PubMed]

44. Basu, A.K. DNA Damage, Mutagenesis and Cancer. Int. J. Mol. Sci. 2018, 19, 970. [CrossRef] [PubMed]

45. Basu, A.K.; Nohmi, T. Chemically-Induced DNA Damage, Mutagenesis, and Cancer. Int. J. Mol. Sci. 2018, 19, 1767. [CrossRef] [PubMed]

46. Hoeijmakers, J.H.J. DNA damage, aging, and cancer. N. Engl. J. Med. 2009, 361, 1914. [CrossRef] [PubMed]

47. Wu, S.; Bai, Y.N.; Pu, H.Q.; He, J.; Zheng, T.Z.; Li, H.Y.; Dai, M.; Cheng, N. Dynamic changes in DNA damage and repair biomarkers with employment length among nickel smelting workers. Biomed. Environ. Sci. 2015, 28, 679-682. [PubMed]

48. Saquib, Q.; Siddiqui, M.A.; Ahmad, J.; Ansari, S.M.; Faisal, M.; Wahab, R.; Alatar, A.A.; Al-Khedhairy, A.A.; Musarrat, J. Nickel oxide nanoparticles induced transcriptomic alterations in HEPG2 cells. Adv. Exp. Med. Biol. 2018, 1048, 163-174. [PubMed]

49. Guillamet, E.; Creus, A.; Farina, M.; Sabbioni, E.; Fortaner, S.; Marcos, R. DNA-damage induction by eight metal compounds in TK6 human lymphoblastoid cells: Results obtained with the alkaline Comet assay. Mutat. Res. 2008, 654, 22-28. [CrossRef] [PubMed]

50. Latvala, S.; Vare, D.; Karlsson, H.L.; Elihn, K. In vitro genotoxicity of airborne Ni-NP in air-liquid interface. J. Appl. Toxicol. 2017, 37, 1420-1427. [CrossRef]

51. Latvala, S.; Hedberg, J.; Di Bucchianico, S.; Moller, L.; Wallinder, I.O.; Elihn, K.; Karlsson, H.L. Nickel release, ROS generation and toxicity of $\mathrm{Ni}$ and $\mathrm{NiO}$ micro- and nanoparticles. PLoS ONE 2016, 11, e0159684. [CrossRef] [PubMed]

52. Qiao, Y.; Ma, L.Y. Quantification of metal ion induced DNA damage with single cell array based assay. Analyst 2013, 138, 5713-5718. [CrossRef] [PubMed]

53. Lou, J.; Jin, L.; Wu, N.; Tan, Y.; Song, Y.; Gao, M.; Liu, K.; Zhang, X.; He, J. DNA damage and oxidative stress in human B lymphoblastoid cells after combined exposure to hexavalent chromium and nickel compounds. Food Chem. Toxicol. 2013, 55, 533-540. [CrossRef] [PubMed]

54. Kim, H.L.; Seo, Y.R. Molecular and genomic approach for understanding the gene-environment interaction between Nrf2 deficiency and carcinogenic nickel-induced DNA damage. Oncol. Rep. 2012, 28, 1959-1967. [CrossRef] [PubMed] 
55. Saplakoglu, U.; Iscan, M.; Iscan, M. DNA single-strand breakage in rat lung, liver and kidney after single and combined treatments of nickel and cadmium. Mutat. Res. 1997, 394, 133-140. [CrossRef]

56. Guo, H.; Wu, B.; Cui, H.; Peng, X.; Fang, J.; Zuo, Z.; Deng, J.; Wang, X.; Deng, J.; Yin, S.; et al. $\mathrm{NiCl} 2$-down-regulated antioxidant enzyme mRNA expression causes oxidative damage in the broiler(')s kidney. Biol. Trace Elem. Res. 2014, 162, 288-295. [CrossRef] [PubMed]

57. Deng, J.; Guo, H.; Cui, H.; Fang, J.; Zuo, Z.; Deng, J.; Wang, X.; Zhao, L. Oxidative stress and inflammatory responses involved in dietary nickel chloride $(\mathrm{NiCl} 2)$-induced pulmonary toxicity in broiler chickens. Toxicol. Res. 2016, 5, 1421-1433. [CrossRef] [PubMed]

58. Shen, C.C.; Shen, D.S.; Shentu, J.L.; Wang, M.Z.; Wan, M.Y. Could humic acid relieve the biochemical toxicities and DNA damage caused by nickel and deltamethrin in earthworms (Eisenia foetida)? Environ. Sci. Process. Impacts 2015, 17, 2074-2081. [CrossRef]

59. Huffnagle, I.M.; Joyner, A.; Rumble, B.; Hysa, S.; Rudel, D.; Hvastkovs, E.G. Dual electrochemical and physiological apoptosis assay detection of in vivo generated nickel chloride induced DNA damage in Caenorhabditis elegans. Anal. Chem. 2014, 86, 8418-8424. [CrossRef] [PubMed]

60. Sen, P.; Costa, M. Pathway of nickel uptake influences its interaction with heterochromatic DNA. Toxicol. Appl. Pharmacol. 1986, 84, 278-285. [CrossRef]

61. Ono, H.; Wada, O.; Ono, T. Distribution of trace metals in nuclei and nucleoli of normal and regenerating rat liver with special reference to the different behavior of nickel and chromium. J. Toxicol. Environ. Health 1981, 8, 947-957. [CrossRef] [PubMed]

62. Fletcher, G.G.; Rossetto, F.E.; Turnbull, J.D.; Nieboer, E. Toxicity, uptake, and mutagenicity of particulate and soluble nickel compounds. Environ. Health Perspect. 1994, 102, 69-79. [PubMed]

63. Oruambo, I.F.; Kachikwu, S.; Idabor, L. Dose-related increased binding of nickel to chromatin proteins; and changes to DNA concentration in the liver of guinea pigs treated with Nigerian light crude oil. Int. J. Environ. Res. Public Health 2007, 4, 211-215. [CrossRef] [PubMed]

64. Yang, W.C.; Swartz, J.R. A filter microplate assay for quantitative analysis of DNA binding proteins using fluorescent DNA. Anal. Biochem. 2011, 415, 168-174. [CrossRef] [PubMed]

65. Bal, W.; Liang, R.; Lukszo, J.; Lee, S.H.; Dizdaroglu, M.; Kasprzak, K.S. Ni(II) specifically cleaves the C-terminal tail of the major variant of histone $\mathrm{H} 2 \mathrm{~A}$ and forms an oxidative damage-mediating complex with the cleaved-off octapeptide. Chem. Res. Toxicol. 2000, 13, 616-624. [CrossRef] [PubMed]

66. Bal, W.; Karantza, V.; Moudrianakis, E.N.; Kasprzak, K.S. Interaction of Nickel(II) with histones: In vitro binding of nickel(II) to the core histone tetramer. Arch. Biochem. Biophys. 1999, 364, 161-166. [CrossRef] [PubMed]

67. Karaczyn, A.A.; Wojciech, B.; North, S.L.; Bare, R.M.; Hoang, V.M.; Fisher, R.J.; Kasprzak, K.S. The octapeptidic end of the C-terminal tail of histone H2A is cleaved off in cells exposed to carcinogenic nickel(II). Chem. Res. Toxicol. 2003, 16, 1555-1559. [CrossRef]

68. Oliveira, S.C.; Corduneanu, O.; Oliveira-Brett, A.M. In situ evaluation of heavy metal-DNA interactions using an electrochemical DNA biosensor. Bioelectrochemistry 2008, 72, 53-58. [CrossRef] [PubMed]

69. Ciccarelli, R.B.; Wetterhahn, K.E. Nickel distribution and DNA lesions induced in rat tissues by the carcinogen nickel carbonate. Cancer Res. 1982, 42, 3544-3549.

70. Bonsignore, R.; Terenzi, A.; Spinello, A.; Martorana, A.; Lauria, A.; Almerico, A.M.; Keppler, B.K.; Barone, G. G-quadruplex vs. duplex-DNA binding of nickel(II) and zinc(II) Schiff base complexes. J. Inorg. Biochem. 2016, 161, 115-121. [CrossRef]

71. Polo-Ceron, D. Cu(II) and Ni(II) Complexes with New Tridentate NNS Thiosemicarbazones: Synthesis, Characterisation, DNA Interaction, and Antibacterial Activity. Bioinorg. Chem. Appl. 2019, 2019, 3520837. [CrossRef] [PubMed]

72. Moloney, J.N.; Cotter, T.G. ROS signalling in the biology of cancer. Semin. Cell Dev. Biol. 2018, 80, 50-64. [CrossRef] [PubMed]

73. Prasad, S.; Gupta, S.C.; Tyagi, A.K. Reactive oxygen species (ROS) and cancer: Role of antioxidative nutraceuticals. Cancer Lett. 2017, 387, 95-105. [CrossRef] [PubMed]

74. Ahamed, M.; Akhtar, M.J.; Alhadlaq, H.A.; Khan, M.A.M.; Alrokayan, S.A. Comparative cytotoxic response of nickel ferrite nanoparticles in human liver HepG2 and breast MFC-7 cancer cells. Chemosphere 2015, 135, 278-288. [CrossRef] [PubMed] 
75. Han, A.; Zou, L.; Gan, X.; Li, Y.; Liu, F.; Chang, X.; Zhang, X.; Tian, M.; Li, S.; Su, L. ROS generation and MAPKs activation contribute to the Ni-induced testosterone synthesis disturbance in rat Leydig cells. Toxicol. Lett. 2018, 290, 36-45. [CrossRef]

76. Kong, L.; Hu, W.C.; Lu, C.C.; Cheng, K.P.; Tang, M. Mechanisms underlying nickel nanoparticle induced reproductive toxicity and chemo-protective effects of vitamin C in male rats. Chemosphere 2019, 218, 259-265. [CrossRef] [PubMed]

77. Terpilowska, S.; Siwicki, A.K. Pro- and antioxidant activity of chromium(III), iron(III), molybdenum(III) or nickel(II) and their mixtures. Chem. Biol. Interact. 2019, 298, 43-51. [CrossRef]

78. Sousa, C.A.; Soares, H.M.V.M.; Soares, E.V. Toxic effects of nickel oxide (NiO) nanoparticles on the freshwater alga Pseudokirchneriella subcapitata. Aquat. Toxicol. 2018, 204, 80-90. [CrossRef]

79. Sousa, C.A.; Soares, H.M.V.M.; Soares, E.V. Nickel Oxide (NiO) Nanoparticles Induce Loss of Cell Viability in Yeast Mediated by Oxidative Stress. Chem. Res. Toxicol. 2018, 31, 658-665. [CrossRef]

80. Das, D.; Das, P.; Moniruzzaman, M.; Sarkar, M.P.; Mukherjee, J.; Chakraborty, S.B. Consequences of oxidative damage and mitochondrial dysfunction on the fatty acid profile of muscle of indian major carps considering metal toxicity. Chemosphere 2018, 207, 385-396. [CrossRef]

81. Gupta, V.; Jatav, P.K.; Verma, R.; Kothari, S.L.; Kachhwaha, S. Nickel accumulation and its effect on growth, physiological and biochemical parameters in millets and oats. Environ. Sci. Pollut. Res. 2017, 24, 23915-23925. [CrossRef] [PubMed]

82. Kong, L.; Gao, X.J.; Zhu, J.Q.; Cheng, K.P.; Tang, M. Mechanisms Involved in Reproductive Toxicity Caused by Nickel Nanoparticle in Female Rats. Environ. Toxicol. 2016, 31, 1674-1683. [CrossRef] [PubMed]

83. Lee, Y.J.; Lim, S.S.; Baek, B.J.; An, J.M.; Nam, H.S.; Woo, K.M.; Cho, M.K.; Kim, S.H.; Lee, S.H. Nickel(II)-induced nasal epithelial toxicity and oxidative mitochondrial damage. Environ. Toxicol. Pharmacol. 2016, 42, 76-84. [CrossRef] [PubMed]

84. Chen, C.Y.; Wang, Y.F.; Lin, Y.H.; Yen, S.F. Nickel-induced oxidative stress and effect of antioxidants in human lymphocytes. Arch. Toxicol. 2003, 77, 123-130. [CrossRef] [PubMed]

85. Costa, M.; Salnikow, K.; Sutherland, J.E.; Broday, L.; Peng, W.; Zhang, Q.; Kluz, T. The role of oxidative stress in nickel and chromate genotoxicity. Mol. Cell. Biochem. 2002, 234-235, 265-275. [CrossRef]

86. Huang, J.; Cui, H.; Peng, X.; Fang, J.; Zuo, Z.; Deng, J.; Wu, B. The association between splenocyte apoptosis and alterations of Bax, Bcl-2 and caspase-3 mRNA expression, and oxidative stress induced by dietary nickel chloride in broilers. Int. J. Environ. Res. Public Health 2013, 10, 7310-7326. [CrossRef] [PubMed]

87. Wu, B.; Cui, H.; Peng, X.; Fang, J.; Zuo, Z.; Deng, J.; Huang, J. Dietary nickel chloride induces oxidative intestinal damage in broilers. Int. J. Environ. Res. Public Health 2013, 10, 2109-2119. [CrossRef] [PubMed]

88. Wu, B.; Cui, H.; Peng, X.; Fang, J.; Zuo, Z.; Deng, J.; Huang, J. Dietary nickel chloride induces oxidative stress, apoptosis and alters Bax/Bcl-2 and caspase-3 mRNA expression in the cecal tonsil of broilers. Food Chem. Toxicol. 2014, 63, 18-29. [CrossRef]

89. Tang, K.; Li, J.; Yin, S.; Guo, H.; Deng, J.; Cui, H. Effects of nickel chloride on histopathological lesions and oxidative damage in the thymus. Health 2014, 6, 2875-2882. [CrossRef]

90. Yin, S.; Guo, H.; Cui, H.; Peng, X.; Fang, J.; Zuo, Z.; Deng, J.; Wang, X.; Tang, K.; Li, J. Nickel Chloride (NiCl2) Induces Histopathological Lesions via Oxidative Damage in the Broiler's Bursa of Fabricius. Biol. Trace Elem. Res. 2016, 171, 214-223. [CrossRef]

91. Ahamed, M.; Ali, D.; Alhadlaq, H.A.; Akhtar, M.J. Nickel oxide nanoparticles exert cytotoxicity via oxidative stress and induce apoptotic response in human liver cells (HepG2). Chemosphere 2013, 93, 2514-2522. [CrossRef] [PubMed]

92. Zou, L.Y.; Su, L.; Sun, Y.F.; Han, A.J.; Chang, X.H.; Zhu, A.; Liu, F.F.; Li, J.; Sun, Y. Nickel sulfate induced apoptosis via activating ROS-dependent mitochondria and endoplasmic reticulum stress pathways in rat Leydig cells. Environ. Toxicol. 2017, 32, 1918-1926. [CrossRef] [PubMed]

93. Di Bucchianico, S.; Gliga, A.R.; Akerlund, E.; Skoglund, S.; Wallinder, I.O.; Fadeel, B.; Karlsson, H.L. Calcium-dependent cyto- and genotoxicity of nickel metal and nickel oxide nanoparticles in human lung cells. Part. Fibre Toxicol. 2018, 15, 32. [CrossRef] [PubMed]

94. Patel, E.; Lynch, C.; Ruff, V.; Reynolds, M. Co-exposure to nickel and cobalt chloride enhances cytotoxicity and oxidative stress in human lung epithelial cells. Toxicol. Appl. Pharmacol. 2012, 258, 367-375. [CrossRef] [PubMed] 
95. Pan, J.J.; Chang, Q.S.; Wang, X.; Son, Y.; Zhang, Z.; Chen, G.; Luo, J.; Bi, Y.Y.; Chen, F.; Shi, X.L. Reactive Oxygen Species-Activated Akt/ASK1/p38 Signaling Pathway in Nickel Compound-Induced Apoptosis in BEAS 2B Cells. Chem. Res. Toxicol. 2010, 23, 568-577. [CrossRef]

96. Henkler, F.; Brinkmann, J.; Luch, A. The role of oxidative stress in carcinogenesis induced by metals and xenobiotics. Cancers 2010, 2, 376-396. [CrossRef]

97. Bal, W.; Kozlowski, H.; Kasprzak, K.S. Molecular models in nickel carcinogenesis. J. Inorg. Biochem. 2000, 79, 213-218. [CrossRef]

98. Srinivas, U.S.; Tan, B.; Vellayappan, B.A.; Jeyasekharan, A.D. Ros and the DNA damage response in cancer. Redox Biol. 2018. [CrossRef]

99. Wu, Q.; Ni, X. ROS-mediated DNA methylation pattern alterations in carcinogenesis. Curr. Drug Targets 2015, 16, 13-19. [CrossRef]

100. Scott, T.L.; Rangaswamy, S.; Wicker, C.A.; Izumi, T. Repair of oxidative DNA damage and cancer: Recent progress in DNA base excision repair. Antioxid. Redox Signal. 2014, 20, 708-726. [CrossRef]

101. Li, R.; Zhao, L.; Zhang, L.; Chen, M.; Dong, C.; Cai, Z. DNA damage and repair, oxidative stress and metabolism biomarker responses in lungs of rats exposed to ambient atmospheric 1-nitropyrene. Environ. Toxicol. Pharmacol. 2017, 54, 14-20. [CrossRef] [PubMed]

102. Barzilai, A.; Yamamoto, K. DNA damage responses to oxidative stress. DNA Repair 2004, 3, 1109-1115. [CrossRef] [PubMed]

103. Wu, D.N.; Liu, B.D.; Yin, J.F.; Xu, T.; Zhao, S.L.; Xu, Q.; Chen, X.; Wang, H.L. Detection of 8-hydroxydeoxyguanosine $(8-\mathrm{OHdG})$ as a biomarker of oxidative damage in peripheral leukocyte DNA by UHPLC-MS/MS. J. Chromatogr. B 2017, 1064, 1-6. [CrossRef] [PubMed]

104. Harris, R.M.; Williams, T.D.; Hodges, N.J.; Waring, R.H. Reactive oxygen species and oxidative DNA damage mediate the cytotoxicity of tungsten-nickel-cobalt alloys in vitro. Toxicol. Appl. Pharm. 2011, 250, 19-28. [CrossRef] [PubMed]

105. Wang, Y.; Wang, S.Y.; Jia, L.; Zhang, L.; Ba, J.C.; Han, D.; Yu, C.P.; Wu, Y.H. Nickel-Refining Fumes Induced DNA Damage and Apoptosis of NIH/3T3 Cells via Oxidative Stress. Int. J. Environ. Res. Public Health 2016, 13, 629. [CrossRef] [PubMed]

106. Ni, W.Q.; Huang, Y.; Wang, X.L.; Zhang, J.W.; Wu, K.S. Associations of neonatal lead, cadmium, chromium and nickel co-exposure with DNA oxidative damage in an electronic waste recycling town. Sci. Total Environ. 2014, 472, 354-362. [CrossRef] [PubMed]

107. Liu, C.M.; Zheng, G.H.; Ming, Q.L.; Chao, C.; Sun, J.M. Sesamin protects mouse liver against nickel-induced oxidative DNA damage and apoptosis by the PI3K-Akt pathway. J. Agric. Food Chem. 2013, 61, 1146-1154. [CrossRef] [PubMed]

108. Di Pietro, A.; Baluce, B.; Visalli, G.; La Maestra, S.; Micale, R.; Izzotti, A. Ex vivo study for the assessment of behavioral factor and gene polymorphisms in individual susceptibility to oxidative DNA damage metals-induced. Int. J. Hyg. Environ. Health 2011, 214, 210-218. [CrossRef]

109. Kelly, M.C.; Whitaker, G.; White, B.; Smyth, M.R. Nickel(II)-catalysed oxidative guanine and DNA damage beyond 8-oxoguanine. Free Radic. Biol. Med. 2007, 42, 1680-1689. [CrossRef]

110. Misra, M.; Olinski, R.; Dizdaroglu, M.; Kasprzak, K.S. Enhancement by L-histidine of nickel(II)-induced DNA-protein cross-linking and oxidative DNA base damage in the rat kidney. Chem. Res. Toxicol. 1993, 6, 33-37. [CrossRef]

111. Kawanishi, S.; Oikawa, S.; Inoue, S.; Nishino, K. Distinct mechanisms of oxidative DNA damage induced by carcinogenic nickel subsulfide and nickel oxides. Environ. Health Perspect. 2002, 110, 789-791. [CrossRef] [PubMed]

112. Xu, S.C.; He, M.D.; Lu, Y.H.; Li, L.; Zhong, M.; Zhang, Y.W.; Wang, Y.; Yu, Z.P.; Zhou, Z. Nickel exposure induces oxidative damage to mitochondrial DNA in Neuro2a cells: The neuroprotective roles of melatonin. J. Pineal Res. 2011, 51, 426-433. [CrossRef] [PubMed]

113. Mo, Y.Q.; Jiang, M.Z.; Zhang, Y.; Wan, R.; Li, J.; Zhong, C.J.; Li, H.Y.; Tang, S.C.; Zhang, Q.W. Comparative mouse lung injury by nickel nanoparticles with differential surface modification. J. Nanobiotechnol. 2019, 17, 2. [CrossRef] [PubMed]

114. Abudayyak, M.; Guzel, E.; Ozhan, G. Nickel oxide nanoparticles are highly toxic to SH-SY5Y neuronal cells. Neurochem. Int. 2017, 108, 7-14. [CrossRef] [PubMed] 
115. Abudayyak, M.; Guzel, E.; Ozhan, G. Nickel oxide nanoparticles induce oxidative DNA damage and apoptosis in kidney cell line (NRK-52E). Biol. Trace Elem. Res. 2017, 178, 98-104. [CrossRef] [PubMed]

116. Dogra, V.; Kaur, G.; Kaur, A.; Kumar, R.; Kumar, S. In vitro assessment of antimicrobial and genotoxic effect of metallosurfactant based nickel hydroxide nanoparticles against Escherichia coli and its genomic DNA. Colloid Surf. B 2018, 170, 99-108. [CrossRef]

117. Boran, H.; Saffak, S. Comparison of Dissolved Nickel and Nickel Nanoparticles Toxicity in Larval Zebrafish in Terms of Gene Expression and DNA Damage. Arch. Environ. Contam. Toxicol. 2018, 74, 193-202. [CrossRef] [PubMed]

118. Magaye, R.; Gu, Y.L.; Wang, Y.F.; Su, H.; Zhou, Q.; Mao, G.C.; Shi, H.B.; Yue, X.; Zou, B.B.; Xu, J.; et al. In vitro and in vivo evaluation of the toxicities induced by metallic nickel nano and fine particles. J. Mol. Histol. 2016, 47, 273-286. [CrossRef]

119. Akerlund, E.; Cappellini, F.; Di Bucchianico, S.; Islam, S.; Skoglund, S.; Derr, R.; Wallinder, I.O.; Hendriks, G.; Karlsson, H.L. Genotoxic and mutagenic properties of $\mathrm{Ni}$ and $\mathrm{NiO}$ nanoparticles investigated by comet assay,-H2AX staining, Hprt mutation assay and ToxTracker reporter cell lines. Environ. Mol. Mutagenesis 2018, 59, 211-222. [CrossRef]

120. Alarifi, S.; Ali, D.; Alakhtani, S.; Al Suhaibani, E.S.; Al-Qahtani, A.A. Reactive oxygen species-mediated DNA damage and apoptosis in human skin epidermal cells after exposure to nickel nanoparticles. Biol. Trace Elem. Res. 2014, 157, 84-93. [CrossRef]

121. Kumar, V.; Mishra, R.K.; Kaur, G.; Dutta, D. Cobalt and nickel impair DNA metabolism by the oxidative stress independent pathway. Metallomics 2017, 9, 1596-1609. [CrossRef] [PubMed]

122. Chatterjee, N.; Walker, G.C. Mechanisms of DNA Damage, Repair, and Mutagenesis. Environ. Mol. Mutagenesis 2017, 58, 235-263. [CrossRef] [PubMed]

123. Rivera, B.; Polak, P.; Foulkes, W.D. Monogenic diseases of DNA repair. N. Engl. J. Med. 2018, $378,491$. [PubMed]

124. Keijzers, G.; Bakula, D.; Scheibye-Knudsen, M. Monogenic Diseases of DNA Repair. N. Engl. J. Med. 2017, 377, 1868-1876. [CrossRef] [PubMed]

125. Hu, J.P.; Hu, Z.H.; Zhang, Y.; Gou, X.J.; Mu, Y.; Wang, L.R.; Xie, X.Q. Metal binding mediated conformational change of XPA protein: A potential cytotoxic mechanism of nickel in the nucleotide excision repair. J. Mol. Model. 2016, 22, 156. [CrossRef] [PubMed]

126. Krueger, I.; Mullenders, L.H.; Hartwig, A. Nickel(II) increases the sensitivity of V79 Chinese hamster cells towards cisplatin and transplatin by interference with distinct steps of DNA repair. Carcinogenesis 1999, 20, 1177-1184. [CrossRef]

127. Hartwig, A.; Mullenders, L.H.F.; Schlepegrell, R.; Kasten, U.; Beyersmann, D. Nickel(II) interferes with the tncision step in nucleotide excision repair in mammalian cells. Cancer Res. 1994, 54, 4045-4051.

128. Hartwig, A.; Asmuss, M.; Ehleben, I.; Herzer, U.; Kostelac, D.; Pelzer, A.; Schwerdtle, T.; Bürkle, A. Interference by Toxic Metal Ions with DNA Repair Processes and Cell Cycle Control: Molecular Mechanisms. Environ. Health Perspect. 2002, 110, 797-799. [CrossRef]

129. Scanlon, S.E.; Scanlon, C.D.; Hegan, D.C.; Sulkowski, P.L.; Glazer, P.M. Nickel induces transcriptional down-regulation of DNA repair pathways in tumorigenic and non-tumorigenic lung cells. Carcinogenesis 2017, 38, 627-637. [CrossRef]

130. Arita, A.; Munoz, A.; Chervona, Y.; Niu, J.; Qu, Q.; Zhao, N.; Ruan, Y.; Kiok, K.; Kluz, T.; Sun, H.; et al. Gene expression profiles in peripheral blood mononuclear cells of Chinese nickel refinery workers with high exposures to nickel and control subjects. Cancer Epidemiol. Prev. Biomark. 2013, 22, 261-269. [CrossRef]

131. Hartwig, A. Carcinogenicity of metal compounds: Possible role of DNA repair inhibition. Toxicol. Lett. 1998, 102-103, 235-239. [CrossRef]

132. Jeggo, P.A.; Pearl, L.H.; Carr, A.M. DNA repair, genome stability and cancer: A historical perspective. Nat. Rev. Cancer 2016, 16, 35-42. [CrossRef]

133. Van Gent, D.C.; Kanaar, R. Exploiting DNA repair defects for novel cancer therapies. Mol. Biol. Cell 2016, 27, 2145-2148. [CrossRef]

134. Jackson, S.P.; Helleday, T. Drugging DNA repair. Science 2016, 352, 1178-1179. [CrossRef]

135. Saez, G.T. DNA injury and repair systems. Int. J. Mol. Sci. 2018, 19, 1902. [CrossRef] 
136. Lin, W.W.; Yuan, N.; Wang, Z.; Cao, Y.; Fang, Y.X.; Li, X.; Xu, F.; Song, L.; Wang, J.; Zhang, H.; et al. Autophagy confers DNA damage repair pathways to protect the hematopoietic system from nuclear radiation injury. Sci. Rep. 2015, 5, 12362. [CrossRef]

137. Ji, W.; Yang, L.; Yu, L.; Yuan, J.; Hu, D.; Zhang, W.; Yang, J.; Pang, Y.; Li, W.; Lu, J.; et al. Epigenetic silencing of O6-methylguanine DNA methyltransferase gene in NiS-transformed cells. Carcinogenesis 2008, 29, 1267-1275. [CrossRef]

138. Iwitzki, F.; Schlepegrell, R.; Eichhorn, U.; Kaina, B.; Beyersmann, D.; Hartwig, A. Nickel(II) inhibits the repair of O6-methylguanine in mammalian cells. Arch. Toxicol. 1998, 72, 681-689. [CrossRef]

139. Chen, H.B.; Giri, N.C.; Zhang, R.H.; Yamane, K.; Zhang, Y.; Maroney, M.; Costa, M. Nickel ions inhibit histone demethylase JMJD1A and DNA repair enzyme ABH2 by replacing the ferrous tron in the catalytic centers. J. Biol. Chem. 2010, 285, 7374-7383. [CrossRef]

140. Chervona, Y.; Arita, A.; Costa, M. Carcinogenic metals and the epigenome: Understanding the effect of nickel, arsenic, and chromium. Metallomics 2012, 4, 619-627. [CrossRef]

141. Wozniak, K.; Blasiak, J. Nickel impairs the repair of UV- and MNNG-damaged DNA. Cell. Mol. Biol. Lett. 2004, 9, 83-94.

142. Hu, W.; Feng, Z.; Tang, M. Nickel (II) enhances benzo[a]pyrene diol epoxide-induced mutagenesis through inhibition of nucleotide excision repair in human cells: A possible mechanism for nickel (II)-induced carcinogenesis. Carcinogenesis 2004, 25, 455-462. [CrossRef]

143. Lee-Chen, S.F.; Wang, M.C.; Yu, C.T.; Wu, D.R.; Jan, K.Y. Nickel chloride inhibits the DNA repair of UV-treated but not methyl methanesulfonate-treated chinese hamster ovary cells. Biol. Trace Elem. Res. 1993, 37, 39-50. [CrossRef]

144. Wozniak, K.; Czechowska, A.; Blasiak, J. Nickel(II) affects poly(ADP-ribose) polymerase-mediated DNA repair in normal and cancer cells. Z. Nat. C 2006, 61, 142-148. [CrossRef]

145. Hartmann, M.; Hartwig, A. Disturbance of DNA damage recognition after UV-irradiation by nickel(II) and cadmium(II) in mammalian cells. Carcinogenesis 1998, 19, 617-621. [CrossRef]

146. Kasprzak, K.S.; Waalkes, M.P.; Poirier, L.A. Antagonism by essential divalent metals and amino acids of nickel(II)-DNA binding in vitro. Toxicol. Appl. Pharmacol. 1986, 82, 336-343. [CrossRef]

147. Kim, Y.J.; Lee, Y.J.; Kim, H.J.; Kim, H.S.; Kang, M.S.; Lee, S.K.; Park, M.K.; Murata, K.; Kim, H.L.; Seo, Y.R. A molecular mechanism of nickel (II): Reduction of nucleotide excision repair activity by structural and functional disruption of p53. Carcinogenesis 2018, 39, 1157-1164. [CrossRef]

148. Morales, M.E.; Derbes, R.S.; Ade, C.M.; Ortego, J.C.; Stark, J.; Deininger, P.L.; Roy-Engel, A.M. Heavy metal exposure influences double strand break DNA repair outcomes. PLoS ONE 2016, 11, e0151367. [CrossRef]

149. Yi, C.; He, C. DNA repair by reversal of DNA damage. CSH Perspect. Biol. 2013, 5, a012575. [CrossRef]

150. Fu, D.; Calvo, J.A.; Samson, L.D. Balancing repair and tolerance of DNA damage caused by alkylating agents. Nat. Rev. Cancer 2012, 12, 104-120. [CrossRef]

151. Gerson, S.L. MGMT: Its role in cancer aetiology and cancer therapeutics. Nat. Rev. Cancer 2004, 4, $296-307$. [CrossRef]

152. Loenarz, C.; Schofield, C.J. Physiological and biochemical aspects of hydroxylations and demethylations catalyzed by human 2-oxoglutarate oxygenases. Trends Biochem. Sci. 2011, 36, 7-18. [CrossRef]

153. Aravind, L.; Koonin, E.V. The DNA-repair protein AlkB, EGL-9, and leprecan define new families of 2-oxoglutarate-and iron-dependent dioxygenases. Genome Biol. 2001, 2, research0007.1. [CrossRef]

154. Permata, T.B.M.; Hagiwara, Y.; Sato, H.; Yasuhara, T.; Oike, T.; Gondhowiardjo, S.; Held, K.D.; Nakano, T.; Shibata, A. Base excision repair regulates PD-L1 expression in cancer cells. Oncogene 2019, 38, 4452-4466. [CrossRef]

155. Krokan, H.E.; Magnar, B.R.S. Base excision repair. CSH Perspect. Biol. 2013, 5, a012583. [CrossRef]

156. Nimrat, C.; Yunfu, L.; Santillan, B.A.; Patricia, Y.; Wilson, J.H. Environmental stress induces trinucleotide repeat mutagenesis in human cells. Proc. Nat. Acad. Sci. USA 2015, 112, 3764-3769.

157. Apostolou, Z.; Chatzinikolaou, G.; Stratigi, K.; Garinis, G.A. Nucleotide excision repair and transcription-associated genome instability. Bioessays 2019, 41, e1800201. [CrossRef]

158. Zhang, G.H.; Ren, J.C.; Luo, M.; Cui, J.; Du, Y.; Yang, D.; Cui, S.; Wang, X.; Wu, W.; Cao, J.; et al. Association of BER and NER pathway polymorphism haplotypes and micronucleus frequencies with global DNA methylation in benzene-exposed workers of China: Effects of DNA repair genes polymorphisms on genetic damage. Mutat. Res. 2019, 839, 13-20. [CrossRef] 
159. Fagbemi, A.F.; Orelli, B.; Schärer, O.D. Regulation of endonuclease activity in human nucleotide excision repair. DNA Repair 2011, 10, 722-729. [CrossRef]

160. Vincent, M.; Jean Philippe, L.; Thilo, R.; Zhou, Y.; Lee, M.Y.; Jean Marc, E. Sequential recruitment of the repair factors during NER: The role of XPG in initiating the resynthesis step. EMBO J. 2014, 27, 155-167.

161. Spivak, G. Nucleotide excision repair in humans. DNA Repair 2015, 36, 13-18. [CrossRef]

162. Sugitani, N.; Sivley, R.M.; Perry, K.E.; Capra, J.A.; Chazin, W.J. XPA: A key scaffold for human nucleotide excision repair. DNA Repair 2016, 44, 123-135. [CrossRef]

163. Friedberg, E.C. How nucleotide excision repair protects against cancer. Nat. Rev. Cancer 2001, 1, $22-33$. [CrossRef]

164. Iyama, T.; Iii, D.M.W. DNA repair mechanisms in dividing and non-dividing cells. DNA Repair 2013, 12, 620-636. [CrossRef]

165. Xing, J.L.; Dinney, C.P.; Shete, S.; Huang, M.S.; Hildebrandt, M.A.; Chen, Z.N.; Gu, J. Comprehensive pathway-based interrogation of genetic variations in the nucleotide excision DNA repair pathway and risk of bladder cancer. Cancer 2012, 118, 205-215. [CrossRef]

166. Bal, W.; Schwerdtle, T.; Hartwig, A. Mechanism of nickel assault on the zinc finger of DNA repair protein XPA. Chem. Res. Toxicol. 2003, 16, 242-248. [CrossRef]

167. Staresincic, L.; Fagbemi, A.F.; Enzlin, J.H.; Gourdin, A.M.; Wijgers, N.; Dunand-Sauthier, I.; Giglia-Mari, G.; Clarkson, S.G.; Vermeulen, W.; Scharer, O.D. Coordination of dual incision and repair synthesis in human nucleotide excision repair. EMBO J. 2009, 28, 1111-1120. [CrossRef]

168. Li, G.M. Mechanisms and functions of DNA mismatch repair. Cell Res. 2008, 18, 85-98. [CrossRef]

169. Martin, S.A.; Lord, C.J.; Ashworth, A. Therapeutic targeting of the DNA mismatch repair pathway. Clin. Cancer Res. 2010, 16, 5107-5113. [CrossRef]

170. Sargent, D.J.; Marsoni, S.; Monges, G.; Thibodeau, S.N.; Labianca, R.; Hamilton, S.R.; French, A.J.; Kabat, B.; Foster, N.R.; Torri, V. Defective mismatch repair as a predictive marker for lack of efficacy of fluorouracil-based adjuvant therapy in colon cancer. J. Clin. Oncol. 2010, 28, 3219-3226. [CrossRef]

171. Karamurzin, Y.; Rutgers, J.K. DNA mismatch repair deficiency in endometrial carcinoma. Int. J. Gynecol. Pathol. 2009, 28, 239-255. [CrossRef] [PubMed]

172. Felsberg, J.; Thon, N.; Eigenbrod, S.; Hentschel, B.; Sabel, M.C.; Westphal, M.; Schackert, G.; Kreth, F.W.; Pietsch, T.; Löffler, M. Promoter methylation and expression of MGMT and the DNA mismatch repair genes MLH1, MSH2, MSH6 and PMS2 in paired primary and recurrent glioblastomas. Int. J. Cancer 2011, 129, 659-670. [CrossRef] [PubMed]

173. Kunkel, T.A.; Erie, D.A. Eukaryotic mismatch repair in relation to DNA replication. Annu. Rev. Genet. 2015, 49, 291-313. [CrossRef] [PubMed]

174. Li, Z.; Pearlman, A.H.; Hsieh, P. DNA mismatch repair and the DNA damage response. DNA Repair 2016, 38, 94-101. [CrossRef] [PubMed]

175. Martin, S.A.; McCabe, N.; Mullarkey, M.; Cummins, R.; Burgess, D.J.; Nakabeppu, Y.; Oka, S.; Kay, E.; Lord, C.J.; Ashworth, A. DNA polymerases as potential therapeutic targets for cancers deficient in the DNA mismatch repair proteins MSH2 or MLH1. Cancer Cell 2010, 17, 235-248. [CrossRef]

176. Fishel, R.; Lee, J.B. Mismatch repair. In DNA Replication, Recombination, and Repair; Springer: Berlin/Heidelberg, Germany, 2016; pp. 305-339.

177. Massey, D.J.; Koren, A. Mismatch repair prefers exons. Nat. Genet. 2017, 49, 1673-1674. [CrossRef] [PubMed]

178. Shrivastav, M.; De Haro, L.P.; Nickoloff, J.A. Regulation of DNA double-strand break repair pathway choice. Cell Res. 2008, 18, 134-147. [CrossRef] [PubMed]

179. Chapman, J.R.; Taylor, M.R.; Boulton, S.J. Playing the end game: DNA double-strand break repair pathway choice. Mol. cell 2012, 47, 497-510. [CrossRef]

180. Li, X.; Heyer, W.D. Homologous recombination in DNA repair and DNA damage tolerance. Cell Res. 2008, 18, 99-113. [CrossRef]

181. Benson, F.E.; Baumann, P.; West, S.C. Synergistic actions of Rad51 and Rad52 in recombination and DNA repair. Nature 1998, 391, 401-404. [CrossRef]

182. Zhao, Z.; Oh, S.; Li, D.P.; Ni, D.J.; Pirooz, S.D.; Lee, J.H.; Yang, S.H.; Lee, J.Y.; Ghozalli, I.; Costanzo, V.; et al. A Dual Role for UVRAG in Maintaining Chromosomal Stability Independent of Autophagy. Dev. Cell 2012, 22, 1001-1016. [CrossRef] [PubMed] 
183. Lieber, M.R.; Ma, Y.; Pannicke, U.; Schwarz, K. Mechanism and regulation of human non-homologous DNA end-joining. Nat. Rev. Mol. Cell. Biol. 2003, 4, 712-720. [CrossRef] [PubMed]

184. Takahashi, S.; Takeda, E.; Kubota, Y.; Okayasu, R. Inhibition of repair of radiation-induced DNA double-strand breaks by nickel and arsenite. Radiat. Res. 2000, 154, 686-691. [CrossRef]

185. Janion, C. Inducible SOS response system of DNA repair and mutagenesis in Escherichia coli. Int. J. Biol. Sci. 2008, 4, 338-344. [CrossRef] [PubMed]

186. Patel, M.; Jiang, Q.; Woodgate, R.; Cox, M.M.; Goodman, M.F. A new model for SOS-induced mutagenesis: How RecA protein activates DNA polymerase V. Crit. Rev. Biochem. Mol. Biol. 2010, 45, 171-184. [CrossRef] [PubMed]

187. Žgur-Bertok, D. DNA damage repair and bacterial pathogens. PLoS Pathog. 2013, 9, e1003711. [CrossRef] [PubMed]

(C) 2019 by the authors. Licensee MDPI, Basel, Switzerland. This article is an open access article distributed under the terms and conditions of the Creative Commons Attribution (CC BY) license (http://creativecommons.org/licenses/by/4.0/). 